\title{
触 New Disease Reports \\ Melampsoridium hiratsukanum reported for the first time on grey alder in Italy
}

\author{
S. Moricca ${ }^{1} *$ and G. Maresi ${ }^{2}$ \\ ${ }^{1}$ Department of Agricultural Biotechnology - Plant Protection Section, Florence University, Piazzale delle Cascine 28, \\ I-50144 Florence, Italy; ${ }^{2}$ FEM-IASMA - Centre for Technology Transfer, Via E. Mach, I-38010 San Michele all'Adige (TN), \\ Italy
}

*E-mail: salvatore.moricca@unifi.it

Received: 22 Feb 2010. Published: 10 May 2010.

Grey alder (Alnus incana) can be found in the Alpine region as a coloniser of alluvial lands along mountain brooks and streams or in dense thickets above the forest line. In the summer of 2008 and 2009, a leaf rust with high disease incidence and severity was recorded on this species in the Campelle valley, a narrow Alpine valley in the mountain range of Lagorai, in Trentino Alto-Adige, Italy. At the end of summer, several trees appeared heavily defoliated with conspicuous crown thinning (Fig. 1). Infected leaves that still remained attached to the trees curled inwards, with their lower surface densely covered by characteristic orange-coloured urediniospores erupting in profusion from a multitude of subepidermal uredinia (Fig. 2).

The fungus was identified as Melampsoridium hiratsukanum based upon symptoms and micro-morphological characteristics (Kurkela et al., 1999). Examination under the light microscope and in the scanning electron microscope revealed uredinia arranged in small groups or unevenly scattered, measuring between 60 and $80 \mu \mathrm{m}$. Also observed were uniformly sparse and regularly echinulate urediniospores (average size $25.3 \times 12.5 \mu \mathrm{m}$ ), ovoid to ellipsoid, sometimes arranged in chains (Fig. 3). The observed M. hiratsukanum differs from the congeneric M. betulinum and M. alni in having longer ostiolar cells in the peridia of the uredinia that extend into long, sharp spines measuring up to $40 \mu \mathrm{m}$ (Fig. 4). Furthermore, M. betulinum and M. alni urediniospores are longer and narrower with a smooth wall and no spines in the apical region. Field observation also provides evidence that $\mathrm{M}$. betulinum, a common pathogen of Betula sp. in the northern hemisphere, is not the cause of the current epidemic since several B. pendula individuals growing at the same site did not exhibit any rust infection. This is the first report of M. hiratsukanum on grey alder in Italy and provides evidence that outbreaks of this rust are spreading on alder species throughout Europe (Hantula et al., 2009). Believed to be native in eastern Asia, this fungus has been recorded in the last two decades in a number of countries, from the Baltic States to Turkey. Similar impacts were also documented in nearby Austria (Riegler-Hager et al., 2003) and Hungary (Szabo, 2002).

\section{Acknowledgements}

We thank the personnel of the Forest and Fauna Service of the Autonomous Province of Trento for bringing the disease to our notice.

\section{References}

Hantula J, Kurkela T, Hendry S, Yamaguchi T, 2009. Morphological measurements and ITS sequences show that the new alder rust in Europe is conspecific with Melampsoridium hiratsukanum in eastern Asia. Mycologia, 622-631. [doi:10.3852/07-164]

Kurkela T, Hanso M, Hantula J, 1999. Differentiating characteristics between Melampsoridium rusts infecting birch and alder leaves. Mycologia 91, 987-992. [doi:10.2307/3761629]

Riegler-Hager H, Scheuer C, Zwetko P, 2003. Der Erlen-Rost Melampsoridium hiratsukanum in Österreich. Wulfenia , 135-143.

Szabo I, 2002. First Report of Melampsoridium hiratsukanum on common alder in Hungary. Plant Pathology 51, 804.

[doi:10.1046/j.1365-3059.2002.00776.x]

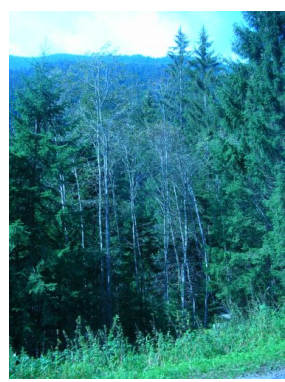

Figure 1

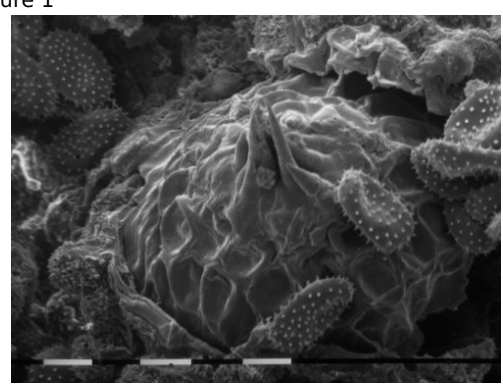

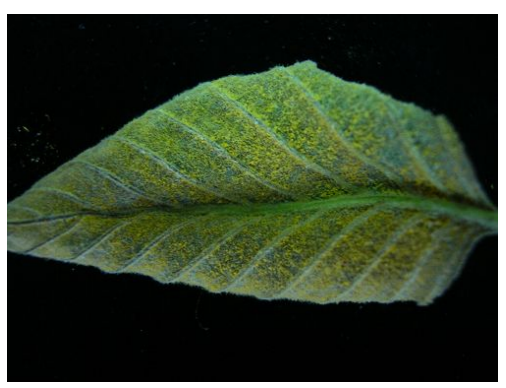

Figure 2

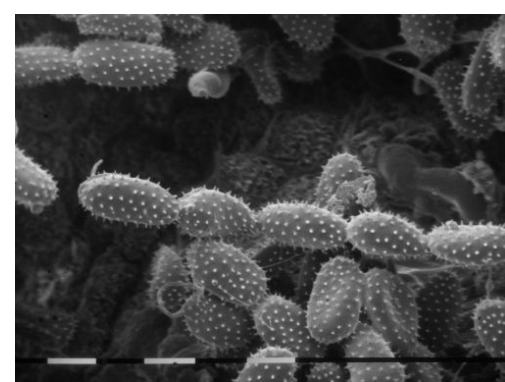

Figure 3

Figure 4

To cite this report: Moricca S, Maresi G, 2010. Melampsoridium hiratsukanum reported for the first time on grey alder in Italy. New Disease Reports 21, 17. [doi:10.5197/j.2044-0588.2010.021.017]

(C) 2010 The Authors

This report was published on-line at www.ndrs.org.uk where high quality versions of the figures can be found. 